AKRUAL 2 (1) (2010): 92-108 $e$-ISSN: 2502-6380

\title{
AKRUAL
}

Jurnal Akuntansi

http://fe.unesa.ac.id/ojs/index.php/akrl

\section{DECISION USEFULNESS APPROACH OF ACCOUNTING INFORMATION: BAGAIMANA INFORMASI AKUNTANSI MENJADI USEFUL?}

\author{
Zarah Puspitaningtyas \\ Dosen Universitas Jember \\ Email: zara_4yu@yahoo.com \\ Artikel diterima: 5 Januari 2010 \\ Terakhir direvisi: 18 Maret 2010
}

\begin{abstract}
Application of decision usefulness approach to produce accounting information that is relevant and reliable. Relevant information, that has the capacity to affect the confidence of investors about future returns, and should be released in a timely manner.The concept of decision usefulness of accounting information plays an important role in identifying problems for users of financial reports and selection of accounting information that users of financial statements to make the best decision. To apply the concept of decision usefulness is necessary linkages with the various theories in economics and finance. Decision usefulness approach assumes that individual decision makers are rational, that is individuals who will choose the action that will yield the highest expected utility.
\end{abstract}

Keywords: Usefulness of Accounting Information, Decision Usefulness Approach

\section{PENDAHULUAN}

Pendekatan decision usefulness of accounting information (Scott, 2009:59) berpandangan bahwa "if we can't prepare theoretically correct financial statements, at least we can try to make financial statements more useful." (jika kita tidak dapat menyusun laporan keuangan yang secara teoritis benar, setidaknya kita dapat mencoba membuat laporan keuangan menjadi lebih berguna). Konsep decision usefulness atas informasi akuntansi memegang peranan penting dalam pengidentifikasian masalah bagi para pengguna laporan keuangan dan penyeleksian informasi akuntansi yang dibutuhkan para pengguna laporan keuangan untuk membuat keputusan terbaik. Konsekuensi dari konsep ini adalah bahwa informasi akuntansi yang terkandung dalam laporan keuangan harus memberikan nilai kegunaan (useful) kepada para penggunanya (users) dalam hal pengambilan keputusan.

Untuk mengaplikasikan konsep decision usefulness diperlukan keterkaitan dengan berbagai teori dalam ilmu ekonomi dan keuangan. Misalnya, dengan memahami teori investasi (investment theory) dan teori pengambilan keputusan (decision theory). Teori investasi merupakan landasan yang tepat bagi investor yang 
rasional untuk memahami sifat dari risiko dalam konteks investasi saham. Teori pengambilan keputusan merupakan landasan yang tepat untuk mulai memahami bagaimana individu-individu mungkin mengambil keputusan dalam kondisi yang tidak pasti dengan mengapresiasi konsep informasi, yang memungkinkan bagi para pengambil keputusan untuk memperbarui keyakinan subyektif mereka mengenai hasil-hasil dari keputusan tersebut yang akan diperoleh di masa akan datang. Teori pengambilan keputusan mengasumsikan bahwa pengambil keputusan (decision makers) adalah individu yang rasional. Konsep individu yang rasional secara sederhana dimaksudkan bahwa dalam membuat suatu keputusan, individu memilih tindakan yang akan menghasilkan expected utility yang paling tinggi. Investor yang rasional diasumsikan sebagai individu yang risk averse, yaitu individu yang mengharapkan untuk mendapatkan tingkat return tertinggi pada tingkat risiko tertentu dari keputusan investasinya (Samuelson \& Marks, 2003:566; Scott, 2009:62).

\section{KAJIAN PUSTAKA}

\section{Pendekatan Decision Usefulness atas Informasi Akuntansi}

Akuntan telah memutuskan bahwa investor merupakan konstituen utama, serta menggunakan teori investasi dan teori pengambilan keputusan dalam memahami tipe informasi akuntansi yang dibutuhkan investor. Hal ini sesuai dengan tujuan laporan keuangan yang ada dalam pernyataan SFAC No.1 tentang the objective of financial reporting for business enterprise (FASB, 1978) (paragraf 5) sebagai berikut:

(1) "Financial reporting should provide information that is useful to present and potential investors and creditors and other users in making rational investment, credit, and similar decisions." (laporan keuangan seharusnya menyediakan informasi yang berguna bagi investor atau kreditor yang ada sekarang maupun calon investor/ kreditor dan para pengguna lain dalam melakukan investasi, kredit, dan keputusan-keputusan serupa yang rasional).

(2) "Financial reporting should provide information to help present and potential investors and creditors and other users in assessing the amounts, timing, and uncertainty of prospective cash receipts from dividends or interest and the proceeds from the sale, redemption, or maturity of securities or loans." (laporan keuangan seharusnya menyediakan informasi untuk membantu investor atau kreditor yang ada sekarang maupun calon investor/ kreditor dan para pengguna lain dalam menaksir (memprediksi) jumlah, penentuan waktu, dan ketidakpastian dari penerimaan kas yang prospektif dari deviden atau bunga dan hasil-hasil yang diperoleh dari penjualan, penebusan, atau jatuh temponya suatu sekuritas atau pinjaman).

Kedua pernyataan tersebut mengimplikasikan bahwa meskipun laporan keuangan memiliki sasaran yang luas, orientasinya terletak pada investor dan kreditor dengan berasumsi bahwa terpenuhinya kebutuhan mereka berarti terpenuhi pula hampir semua kebutuhan para pengguna lainnya. Investor, dalam Kerangka Dasar Penyusunan dan Penyajian Laporan Keuangan tentang Pengguna dan Kebutuhan Informasi, didefinisikan sebagai penanam modal berisiko yang berkepentingan 
dengan risiko yang melekat serta hasil pengembangan dari investasi yang mereka lakukan (Standar Akuntansi Keuangan, 2009:2).

Pernyataan dalam SFAC No.1 jelas memberikan mandat pada profesi akuntansi untuk menyajikan laporan keuangan yang berguna (useful) bagi para pengguna dalam rangka membuat keputusan bisnis. Lebih lanjut, SFAC No.1 menyajikan suatu adaptasi penting dari teori keputusan bagi penyusunan laporan keuangan, bahwa teori keputusan ini berorientasi kepada pembuatan keputusan investasi bagi individu yang rasional (Machfoedz, 1999; Scott, 2009:76). Oleh karenanya, pengujian atas manfaat informasi akuntansi penting dilakukan. Pendekatan decision usefulness atas informasi akuntansi merupakan suatu pendekatan terhadap laporan keuangan yang berbasis biaya historis agar menjadi lebih berguna.

Pendekatan ini menitikberatkan pada para pengguna laporan keuangan, keputusan mereka, informasi yang mereka butuhkan, serta kemampuan mereka memproses informasi akuntansi (Wignjohartojo, 1995:41). Terdapat dua pertanyaan penting dalam mengadopsi pendekatan decision usefulness atas informasi akuntansi, yaitu: (1) siapa saja para pengguna laporan keuangan. Terdapat banyak konstituen (kelompok-kelompok pengguna), seperti: investor, manajer, serikat buruh, standard setters, dan pemerintah. Terdapat banyak pihak yang berkepentingan atas laporan keuangan, oleh karenanya dengan mengidentifikasi pengguna (pihak yang berkepentingan) diharapkan akan dapat ditentukan bagaimana bentuk laporan keuangan atau informasi akuntansi apa saja yang harus disajikan dalam laporan keuangan; dan (2) apa saja masalah keputusan bagi para pengguna laporan keuangan. Akuntan akan lebih memahami berbagai kebutuhan informasi yang diperlukan oleh para pengguna laporan keuangan dengan mengetahui masalah-masalah keputusan yang dihadapi oleh para pengguna laporan keuangan.

Penyusunan laporan keuangan seharusnya mempertimbangkan informasi akuntansi yang dibutuhkan para pengguna laporan keuangan tersebut. Dengan kata lain, akuntan seharusnya menyesuaikan informasi akuntansi yang disajikan dalam laporan keuangan dengan kebutuhan-kebutuhan para pengguna laporan keuangan sehingga dapat menghasilkan pengambilan keputusan yang lebih baik. Dengan cara ini, informasi akuntansi yang disajikan dalam laporan keuangan akan menjadi lebih berguna (Scott, 2009:59). Tujuan laporan keuangan adalah menyediakan informasi yang menyangkut posisi keuangan, kinerja, serta perubahan posisi keuangan suatu perusahaan yang berguna bagi para pengguna dalam pengambilan keputusan ekonomi. Namun demikian, laporan keuangan tidak menyediakan semua informasi yang mungkin dibutuhkan pengguna dalam pengambilan keputusan ekonomi karena secara umum menggambarkan pengaruh keuangan dan kejadian di masa lalu. Oleh karenanya, untuk dapat membuat keputusan ekonomi, para pengguna laporan keuangan memerlukan evaluasi atau analisis berdasarkan informasi akuntansi yang terkandung dalam laporan keuangan (Moon \& Keasey, 1992; Banker et al., 1993; Eccles \& Holt, 2005; Alattar \& Al-Khater, 2007; Standar Akuntansi Keuangan, 2009:3). 
Kemampuan laporan keuangan untuk memberikan informasi akuntansi yang berguna bagi investor tidak terlepas dari permasalahan karakteristik kualitatif dari laporan keuangan itu sendiri. Karakteristik kualitatif merupakan ciri khas yang membuat informasi akuntansi dalam laporan keuangan menjadi berguna bagi para penggunanya. Standar Akuntansi Keuangan (2009:5) menyebutkan bahwa terdapat empat karakteristik kualitatif pokok, yaitu: (1) dapat dipahami, (2) relevan, (3) keandalan, dan (4) dapat diperbandingkan. Karakteristik kualitatif informasi akuntansi, yaitu: relevance dan reliability merupakan kualitas utama yang diperlukan agar penyajian laporan keuangan menjadi berguna bagi pengambilan keputusan investasi dengan mengoperasionalkan pendekatan decision usefulness. Informasi yang relevan (relevance) adalah informasi yang tepat waktu (timeliness), yaitu informasi yang tersedia bagi decision maker dan memiliki kapasitas yang dapat mempengaruhi decision makers dalam membuat keputusan dengan mengevaluasi peristiwa masa lalu, masa kini, atau masa akan datang, menegaskan atau mengoreksi hasil evaluasi pada masa lalu. Selain itu, informasi akuntansi dapat dikatakan relevan jika mempunyai nilai prediktif (predictive value) dan nilai umpan balik (feedback value). Jadi, informasi yang relevan adalah informasi yang mempunyai kapasitas untuk mempengaruhi keyakinan investor mengenai tingkat return yang diharapkan diterima di masa akan datang (future returns), dan seharusnya di-release secara tepat waktu. Selanjutnya, informasi akuntansi dapat dikatakan reliabel (reliability) apabila suatu informasi akuntansi itu bebas dari bias atau bebas dari pengertian yang menyesatkan, bebas dari kesalahan material, dan dapat diandalkan para penggunanya sebagai penyajian yang tulus dan jujur dari yang seharusnya disajikan (verifiability, neutrality, representational faithfulness). Jadi, informasi yang reliabel adalah informasi yang mewakili apa yang dinyatakan dan diukur oleh informasi tersebut.

Bahwa, suatu informasi haruslah menyajikan kebenaran secara tepat dan bebas dari bias (FASB, 1980; Eccles \& Holt, 2005; Maines \& Wahlen, 2006; Standar Akuntansi Keuangan, 2009:5-9; Scott, 2009:76).

Penyajian laporan keuangan tidak mungkin menyajikan laporan keuangan dengan tingkat relevansi dan reliabilitas secara penuh karena konsekuensinya akan terjadi trade-off antara relevansi dan reliabilitas sebagai bagian dari kualitas informasi yang diinginkan. Adanya permasalahan bahwa laporan keuangan seharusnya menyajikan informasi yang berguna bagi investor dan pemakai lain, maka laporan keuangan harus mempertimbangkan tingkat relevansi dan reliabilitas atas penyajian informasi yang terkandung didalamnya. Kedua kriteria tersebut akan mengalami trade-off jika digunakan secara bersamaan. Selama ini penyajian laporan keuangan dengan berbasis biaya historis (historical cost) masih dinilai relatif reliabel, sebab biaya (cost) pada aktiva atau kewajiban perusahan masih obyektif untuk estimasi. Akan tetapi, kelemahan penyajian laporan keuangan berbasis biaya historis dinilai tidak memiliki kemampuan prediktif (tidak relevan) terhadap kemampuan perusahaan dalam memanfaatkan peluang dan bereaksi dalam situasi yang merugikan (Scott, 2009:41\&58). 
Pembahasan yang mengarah pada suatu konsep penting dalam ilmu akuntansi, yaitu konsep decision usefulness, konsep tentang kebermanfaatan (kegunaan) dalam pengambilan keputusan. Pendekatan decision usefulness dapat digunakan untuk membuat informasi akuntansi yang terkandung dalam laporan keuangan yang berbasis biaya historis menjadi lebih berguna (useful). Akuntan sebagai penyaji informasi akuntansi tidak akan dapat menjadikan laporan keuangan menjadi lebih berguna sampai mengetahui apa sebenarnya makna manfaat (kegunaan) dari informasi yang disajikan bagi para penggunanya. Kualitas penting informasi yang terkandung dalam laporan keuangan adalah kemudahannya untuk segera dapat dipahami oleh para pengguna (Scott, 2009:59).

\section{Nilai Informasi Akuntansi bagi Investor}

Nilai informasi akuntansi yang berguna bagi investor secara empirik diinvestigasikan melalui hubungan antara data akuntansi yang di-release kepada publik dengan perubahan harga sekuritas suatu perusahaan. Jika hubungannya adalah signifikan, maka bukti menunjukkan bahwa informasi akuntansi adalah berguna (useful) dengan respek terhadap penilaian perusahaan. Berkenaan dengan kecepatan sekuritas dalam pasar untuk merespon informasi baru yang di-release disebut sebagai the efficient market hypothesis (EMH). Definisi klasik dari efisiensi pasar adalah bahwa: (1) pasar secara penuh mencerminkan informasi yang tersedia, dan (2) harga pasar bereaksi secara cepat (seketika itu juga) terhadap informasi baru. Bahwa, informasi baru adalah secara cepat dituangkan dalam harga sekuritas. Ketika hal ini terjadi, informasi tersebut mempunyai kandungan informasi (information content) (Wolk et al., 2004:235).

Kunci utama untuk mengukur pasar yang efisien secara informasi adalah hubungan antara harga sekuritas dan informasi. Pertanyaannya adalah informasi mana yang dapat digunakan untuk menilai pasar yang efisien: Apakah informasi yang lama? Informasi yang sedang dipublikasikan? Atau semua informasi, termasuk informasi privat? Tiga bentuk utama efisiensi pasar berdasarkan tiga bentuk informasi (Hartono, 2008:492; Samsul, 2006:272; Wolk et al., 2004:236), yaitu:

a. Efisiensi Pasar Bentuk Lemah (Weak Form)

Pasar dikatakan efisien dalam bentuk lemah (weak form) jika harga-harga sekuritas mencerminkan secara penuh (fully reflect) informasi masa lalu. Informasi masa lalu merupakan informasi yang sudah terjadi. Bentuk efisiensi pasar lemah ini berkaitan dengan teori langkah acak (random walk theory) yang menyatakan bahwa data masa lalu tidak berhubungan dengan nilai sekarang. Jika pasar efisien secara bentuk lemah, maka nilai-nilai masa lalu tidak dapat digunakan untuk memprediksi harga sekarang. Ini berarti bahwa untuk pasar efisien bentuk lemah, investor tidak dapat menggunakan informasi masa lalu untuk mendapatkan keuntungan yang tidak normal. 
b. Efisiensi Pasar Setengah Kuat (Semistrong Form)

Pasar dikatakan efisien setengah kuat (semistrong form) jika harga-harga sekuritas secara penuh mencerminkan (fully reflect) semua informasi yang dipublikasikan (all publicly available information), termasuk informasi yang berada dalam laporan-laporan keuangan perusahaan emiten. Pada pasar efisien dalam bentuk setengah kuat tidak ada investor atau grup investor yang dapat menggunakan informasi yang dipublikasikan untuk mendapatkan keuntungan tidak normal dalam jangka waktu yang lama.

Informasi yang dipublikasikan dapat berbentuk sebagai berikut (Hartono, 2008:493):

1. Informasi yang dipublikasikan yang hanya mempengaruhi harga sekuritas perusahaan yang mempublikasikan informasi tersebut. Informasi yang dipublikasikan ini merupakan informasi dalam bentuk pengumuman oleh perusahaan emiten. Informasi ini umumnya berhubungan dengan peristiwa yang terjadi di perusahaan emiten (corporate event).

2. Informasi yang dipublikasikan yang mempengaruhi harga-harga sekuritas sejumlah perusahaan. Informasi yang dipublikasikan ini dapat berupa peraturan pemerintah atau peraturan regulator yang hanya berdampak pada harga-harga sekuritas perusahaan-perusahaan yang terkena regulasi tersebut. sebuah bank, tetapi juga mungkin semua emiten dalam industri perbankan.

3. Informasi yang dipublikasikan yang mempengaruhi harga-harga sekuritas semua perusahaan yang terdaftar di pasar saham. Informasi ini dapat berupa peraturan pemerintah atau peraturan regulator yang berdampak ke semua perusahaan emiten.

c. Efisiensi Pasar Bentuk Kuat (Strong Form)

Pasar dikatakan efisien dalam bentuk kuat (strong form) jika harga-harga sekuritas secara penuh mencerminkan semua informasi yang tersedia termasuk informasi privat. Jika pasar efisien dalam bentuk ini, tidak ada individual investor atau grup dari investor yang dapat memeproleh keuntungan tidak normal (abnormal return) karena mempunyai informasi privat.

Tabel 1. Hubungan Bentuk Efisiensi Pasar Sekuritas dan Informasi

\begin{tabular}{ll}
\hline \multicolumn{1}{c}{$\begin{array}{c}\text { Bentuk Efisiensi Pasar } \\
\text { Sekuritas }\end{array}$} & \multicolumn{1}{c}{ Informasi yang Digunakan } \\
\hline Weak-form & Harga dan volume masa lalu \\
Semistrong-form & Harga, volume masa lalu, dan informasi publik \\
Strong-form & $\begin{array}{l}\text { Harga, volume masa lalu, informasi publik, dan } \\
\text { informasi privat } \\
\end{array}$ \\
& (informasi yang tidak dipublikasikan) \\
\hline
\end{tabular}

Sumber: Beaver (1989:137); Haugen (2001:574); Reilly \& Brown (2006:171); Samsul (2006:272); Kodrat dan Herdinata (2009:10). 
Berkenaan dengan keputusan investasi yang tepat, maka diperlukan kecanggihan pasar (sophisticated). Artinya, investor menerima informasi, mengolah informasi dengan benar dengan melakukan analisis yang mendalam untuk memperkirakan besarnya dampak informasi terhadap harga sekuritas yang bersangkutan. Hartono (2008:497) menyebutnya dengan efisiensi pasar secara keputusan (decisionally eficient market). Konsep pasar efisien secara keputusan mempertimbangkan dua faktor, yaitu ketersediaan informasi dan kecanggihan (sophisticated) investor. Investor yang sophisticated tidak akan mudah dibodohi (fooled) oleh emiten karena akan mennganalisis seluruh informasi lebih lanjut untuk menentukan apakah informasi tersebut signal yang sahih dan dapat dipercaya. Jika ternyata signal tersebut tidak sahih dan investor naive, reaksi positif terhadap informasi merupakan reaksi yang salah sehingga dapat dikatakan pasar belum efisien secara keputusan. Jika pasar efisien secara keputusan, investor akan dapat mengetahui bahwa signal tersebut adalah signal yang salah. Implikasinya investor akan menganggap informasi tersebut sebagai bad news, karena informasi tersebut tidak mempunyai prospek yang baik bagi emiten. Jadi, yang membedakan keyakinan investor atas keputusan investasinya ialah informasi yang diterima serta pengetahuan atau pengalaman yang dimilikinya (Abarbanell et al., 1995).

\section{Information Usefulness}

Teori pengambilan keputusan dan konsep informasi memberikan secara tepat cara mendefinisikan informasi (Scott, 2009:68) yaitu: "information is evidence which has the potential to affect an individual's decision." (informasi adalah bukti-bukti yang berpotensi mempengaruhi keputusan seorang individu). Informasi adalah bersifat individu, artinya individu mungkin akan memberikan reaksi yang berbeda terhadap sumber informasi yang sama. Hal ini menunjukkan bahwa individu menerima informasi dan merevisi keyakinan secara berurutan dalam proses berkelanjutan melalui penerimaan informasi yang terkandung dalam laporan keuangan dan juga dari sumber informasi lain seperti media, dan pengumuman lain yang dapat mempengaruhi keputusan. Sehubungan dengan hal tersebut sebagai sumber informasi, laporan keuangan adalah penyedia informasi akuntansi yang relevan dan reliabel.

Penting dipahami di sini mengapa informasi akuntansi yang terkandung dalam laporan keuangan berguna. Tujuan utama dari akuntansi keuangan ialah menyajikan informasi yang berguna(usefulness) bagi para pemakai dalam pengambilan keputusan (Day, 1986; Beaver, 1989:22). Lingkungan akuntansi sangatlah kompleks, karena produk dari akuntansi adalah informasi (sebagai suatu komoditas yang kuat dan penting). Salah satu alasan kompleksitas ini adalah bahwa setiap individu tidak selalu menunjukkan reaksi yang sama terhadap informasi yang sama (Kim \& Verrecchia, 1997). Sebagai contoh, seorang investor berpengalaman mungkin bereaksi positif terhadap penilaian aset-aset dan liabilitas perusahaan tertentu pada nilai yang wajar (fair value) berdasarkan pemikiran bahwa hal ini akan membantu memprediksi kinerja perusahaan tersebut di masa akan datang. Istilah "fair value" atau "nilai yang 
wajar" adalah ungkapan yang umum digunakan untuk menyebut penilaian aset atau liabilitas manapun berdasarkan nilai pasarnya. Investor lainnya mungkin tidak sepositif itu, barangkali karena mereka merasa bahwa informasi mengenai nilai yang wajar itu tidak dapat diandalkan, atau hanya karena mereka terbiasa dengan informasi biaya historis. Dalam hal ini, investor memerlukan informasi akuntansi sebagai dasar analisis bagi keputusan investasinya. Informasi akuntansi yang lengkap, akurat serta tepat waktu memberikan peluang bagi investor untuk mengambil keputusan secara rasional sehingga mencapai hasil sesuai yang diharapkan (Gniewosz, 1990; Bamber et al., 1997; Lawrence \& Kercsmar, 1999; Sembiring, 2005; Landsman, 2007; Suwarjono, 2008:167; Scott, 2009:9).

Akuntansi dapat didefinisikan berdasarkan dua aspek penting, yaitu: (1) penekanan pada aspek fungsi yaitu pada penggunaan informasi akuntansi, dan (2) penekanan pada aspek aktivitas dari orang yang melaksanakan proses akuntansi. Berdasarkan aspek fungsi, akuntansi didefinisikan sebagai suatu disiplin ilmu yang menyajikan informasi yang penting untuk melakukan suatu tindakan yang efisien dan mengevaluasi suatu aktivitas dari organisasi. Informasi tersebut penting untuk perencanaan yang efektif, pengawasan dan pembuatan keputusan oleh manajemen serta memberikan pertanggungjawaban organisasi kepada investor, kreditor, pemerintah, dan pihak-pihak lain yang berkepentingan. Sedangkan, berdasarkan aspek aktivitas, orang yang melaksanakan proses akuntansi antara lain harus mengidentifikasikan data yang relevan dalam pengambilan keputusan, memproses atau menganalisa data yang relevan, dan mengubah data menjadi informasi yang dapat berguna untuk pengambilan keputusan (Siegel \& Marconi, 1989:1-6). Berdasarkan uraian tersebut dapat disimpulkan bahwa informasi yang berguna bagi pengambilan keputusan lebih menekankan pada isi atau kandungan informasi (content of information) serta ketepatan waktu dalam memberikan keyakinan bagi investor atau mengubah keyakinan awal (prior belief) pengguna laporan keuangan agar segera bereaksi dan informasi ini bersaing dengan sumber informasi lain (Ball \& Brown, 1968).

Agar dapat berguna, penyajian informasi akuntansi harus dapat membantu memprediksikan hasil-hasil pengembalian investasi di masa akan datang. Inti dari hubungan antara informasi laporan keuangan yang tengah berjalan dan kinerja perusahan yang akan datang adalah probabilitas. Probabilitas tersebut disebut sebagai sistem informasi yang memberikan probabilitas obyektif dari setiap bukti laporan keuangan yang memungkinkan. Konsep kemampuan sistem informasi memberikan informasi yang berguna dalam memahami peranan informasi dalam pembuatan keputusan. Informasi akuntansi yang berguna (information usefulness) bagi pengambilan keputusan harus mempunyai kualitas informasi dan dipengaruhi oleh faktor-faktor seperti untuk apa keputusan dibuat, metode pengambilan keputusan yang dibuat, informasi yang dimiliki dari sumber-sumber lain, dan kapasitas pembuat keputusan memproses informasi. Untuk memenuhinya, maka informasi yang dihasilkan harus dapat dimengerti dan berguna bagi pengambil keputusan, yaitu bahwa informasi akuntansi haruslah relevan dan reliabel. SFAC No. 2 (FASB, 1980) 
mengungkapkan tentang karakteristik kualitatif dari informasi akuntansi (qualitative characteristics of accounting information) yang diperlukan agar penyajian laporan keuangan menjadi berguna bagi pembuatan keputusan investasi dengan mengoperasionalkan pendekatan decision usefulness. Seperti telah disebutkan, karakteristik informasi yang dimaksud adalah informasi yang relevan (relevance) dan informasi yang reliabel (reliability). Relevansi dan reliabilitas merupakan kualitas utama yang membuat informasi akuntansi menjadi berguna untuk pembuatan keputusan.

\section{Relevance}

SFAC No. 2 memberikan definisi relevance sebagai berikut:

"Relevant accounting information is capable of making a difference in a decision by helping users to form predictions about the outcomes of past, present, and future events or to confirm or correct prior expectations. Information can make a difference to decisions by improving decision makers' capacities to predict or by providing feedback on earlier expectations. Usually, information does both at once, because knowledge about the outcomes of actions already taken will generally improve decision makers' abilities to predict the results of similar future actions. Without a knowledge of the past, the basis for a prediction will usually be lacking. Without an interest in the future, knowledge of the past is sterile." (informasi akuntansi yang relevan mampu membuat perbedaan dalam suatu keputusan dengan membantu para pengguna membentuk prediksi mengenai hasil dari kejadian-kejadian di masa lalu, masa kini, dan masa akan datang, atau mengonfirmasi atau mengoreksi harapan-harapan sebelumnya. Informasi dapat membuat perbedaan bagi keputusan dengan meningkatkan kemampuan para pembuat keputusan untuk melakukan prediksi atau dengan memberi umpan balik atas harapan-harapan sebelumnya. Biasanya, informasi melakukan kedua hal tersebut bersamaan, karena pengetahuan mengenai hasil-hasil tindakan yang telah dilakukan biasanya akan mempengaruhi kemampuan para pembuat keputusan untuk memprediksi hasil-hasil tindakan serupa di masa akan datang. Tanpa pengetahuan akan masa lalu, landasan untuk melakukan prediksi pun tidak akan ada. Tanpa adanya minat terhadap masa akan datang, pengetahuan akan masa lalu pun mandul).

Inti dari definisi tersebut adalah bahwa informasi adalah relevan jika membantu para pengguna laporan keuangan untuk membentuk prediksi-prediksi atas peristiwa (seperti, kinerja di masa akan datang dan hasil-hasil yang diperoleh). Dengan memperluas definisi relevansi hingga mencakup informasi yang dapat membantu investor membentuk estimasi-estimasi hasil di masa akan datang, maka cakupan informasi agar menjadi relevan sangat diperluas (Scott, 2009:86). Accounting Principle B Statement No. 4 (pararaf 88) menyatakan bahwa relevansi merupakan informasi akuntansi yang relevan yang mempunyai pengaruh terhadap keputusan ekonomis bagi pengguna informasi akuntansi yang tersaji. 


\section{Reliability}

Definisi reliability menurut SFAC No. 2 (FASB, 1980) adalah bahwa untuk menjadi reliabel maka suatu informasi tersebut haruslah menyajikan informasi yang faithfullness, verifiability, dan neutrality. Faithfulness bahwa informasi yang disajikan adalah sesuai dengan tujuan penyajian (kejujuran, kepatuhan, kewajaran). Verifiability adalah bahwa informasi yang disajikan dapat diuji (dibuktikan) kebenarannya. Dan, neutrality adalah bahwa informasi yang disajikan harus netral dan bebas dari bias.

Informasi yang tersaji dalam laporan keuangan harus dapat diandalkan jika cukup terbebas dari bias (kesalahan dan penyimpangan) merupakan suatu penyajian yang jujur (wajar). Keandalan informasi ini diperlukan oleh individu-individu yang tidak mempunyai cukup waktu ataupun keahlian untuk memeriksa isi sebenarnya dari informasi yang disajikan. Konsep informasi berguna dan sangat powerfull ialah dalam pemahaman peran informasi pada pengambilan keputusan. Informasi akuntansi untuk menjadi berguna harus memberi suatu sistem informasi yang informatif yang mengaitkan laporan keuangan berjalan dengan hasil-hasil dan realisasi keadaan di masa akan datang. Relevansi dan reliabilitas merupakan karakteristik informatif yang membuat informasi akuntansi menjadi berguna. Informasi yang relevan adalah informasi yang mampu mempengaruhi keyakinan investor mengenai hasil-hasil yang akan diperoleh di masa akan datang, dan seharusnya di-release pada waktu yang tepat. Informasi yang reliabel secara loyal mewakili apa yang dinyatakan dan diukur oleh informasi tersebut. Suatu informasi haruslah tepat dan bebas dari bias.

\section{Konsep Utility dalam Decision Theory}

Teori pengambilan keputusan didasari oleh konsep utility (kepuasan) yang dikemukakan oleh Jeremy Bentham (1780), William Stanley Jevons (1871), Leon Walras (1871), dan Carl Menger (1871). Utilitas merupakan jumlah dari kesenangan atau kepuasan relatif yang dicapai, dengan jumlah ini seseorang bisa menentukan meningkat atau menurunnya utilitas dalam upaya untuk meningkatkan kepuasan. Berdasarkan konsep ini, setiap tindakan individu bertujuan memaksimalkan jumlah utilitas untuk mencapai kepuasaan.Bentham mengembangkan gagasan kepuasan dan membawa pertimbangan maksimalisasi kepuasan ke dalam analisa ekonomi, cita-cita yang diperjuangkan terungkap dalam semboyan "the greatest good to the greatest number", bahwa kebahagiaan atau kebaikan terbesar bagi sebagian terbesar orang sebagai suatu ukuran untuk menilai tindakan manusia dimana setiap institusi sosial dinilai berdasarkan faedah atau manfaat (utility) yang disumbangkan untuk kepentingan (kesejahteraan) manusia individual (Louis, 1971:63; Pressman, 2002:37; Sanusi, 2004:76).

Jevons dalam Louis (1971:111) mengungkapkan konsep kepuasan marjinal (marginal utility) dengan menggunakan matematika untuk menerapkan hubungan antara nilai dengan manfaat (value and utility), bahwa harga relatif tergantung kepada penilaian subyektif orang tentang kepuasan yang didapatkan dari pembelian barangbarang yang berbeda. Pendapat Walras dalam (Pressman, 2002:77; Sanusi, 2004:90) 
mengungkapkan gagasan kepuasan marjinal dengan mendukung individualisme metodologis, yakni keyakinan bahwa semua penjelasan fenomena ekonomi seharusnya berdasarkan tindakan individu dalam memilih.

Menger dalam Pressman, (2002:88) mengemukakan teori keputusan marjinal dari nilai dan prinsip kepuasan marjinal yang semakin berkurang, bahwa nilai lebih ditentukan oleh faktor subyektif (kepuasan atau permintaan) ketimbang faktor obyektif (biaya produksi atau persediaan). Nilai (value) berasal dari kepuasaan kebutuhan manusia. Pendapat Menger diperkuat oleh Scott (2009:13) menyebutkan bahwa pengambilan keputusan investasi oleh investor dilakukan secara rasional dalam rangka memaksimalkan utilitasnya, secara rata-rata para investor memanfaatkan informasi akuntansi keuangan sebagai pertimbangan dalam keputusan investasinya.

\section{Individu yang Rasional}

Konsep mengenai seorang individu yang rasional dalam teori pengambilan keputusan bermakna bahwa dalam mengambil keputusan, tindakan yang dipilih adalah yang menghasilkan utilitas tertinggi yang diharapkan. Konsep individu yang rasional ini menyiratkan bahwa individu tersebut mencari informasi tambahan yang berkaitan dengan keputusan yang akan diambil, dan menggunakannya untuk mengubah keyakinan awalnya. Konsep decision usefulness, mengasumsikan bahwa individu adalah rasional dalam mengambil suatu keputusan. Jika individu tidak mengambil keputusan dengan cara yang rasional dan dapat diprediksi, maka akan sulit bagi akuntan, atau siapapun juga, untuk mengetahui informasi mana yang dinilai berguna. Ada tiga jenis investor berdasarkan preferensi investor terhadap risiko (Pappas \& Hirschey, 1995: 358; Samuelson \& Marks, 2003:566; Halim, 2005:42; Samsul, 2006:161; Bodie et al. 2009:168-170).

Pertama ialah investor yang menyukai risiko atau tipe investor yang berani mengambil risiko (risk seeker, risk takers, risk lover, risk loving) merupakan investor yang apabila dihadapkan pada dua pilihan investasi yang memberikan tingkat return yang sama dengan risiko yang berbeda, maka ia akan lebih suka mengambil investasi dengan risiko yang lebih tinggi. Kedua ialah investor yang netral terhadap risiko (risk neutral) merupakan investor yang akan meminta kenaikan tingkat return yang sama untuk setiap kenaikan risiko. Tipe investor ini hanya akan mengambil risiko yang sebanding dengan return yang akan diperolehnya. Dan, ketiga adalah investor yang tidak menyukai atau menghindari risiko (risk averter, risk averse, risk aversion) merupakan investor yang apabila dihadapkan pada dua pilihan investasi yang memberikan tingkat return yang sama dengan risiko yang berbeda, maka ia akan lebih suka mengambil investasi dengan risiko yang lebih rendah.

Informasi akuntansi yang terkandung dalam laporan keuangan, yaitu Laporan Neraca, Laporan Laba Rugi, Laporan Cash Flow, Laporan Perubahan Ekuitas, dan Catatan Atas Laporan Keuangan. Masing-masing laporan keuangan tersebut akan menunjukkan peran dan fungsinya masing-masing. Bagi pengguna seperti investor, kreditor, pemerintah, dan pengguna lainnya akan menggunakan salah satu informasi 
laporan keuangan tersebut untuk mendukung pengambilan keputusannya. Kebutuhan investor pada informasi mengenai ketidakpastian return investasi masa datang akan sama baiknya dengan nilai harapan investor. Artinya, investor yang rasional membutuhkan informasi mengenai risk yang sama baiknya dengan expected value dari return.

Investor yang rasional selain diasumsikan sebagai individu yang risk-averse (menghindari risiko), seringkali juga diasumsikan sebagai individu yang sifatnya riskneutral (netral risiko). Hal ini berarti bahwa individu mengevaluasi investasiinvestasi yang berisiko hanya melalui hasil-hasil yang diharapkan, sedangkan risiko itu sendiri tidak dinilai sebagai masalah. Netralitas risiko mungkin merupakan asumsi yang masuk akal. Namun demikian, menghindari risiko (risk-averse) adalah asumsi yang lebih realistis dalam banyak kejadian. Konsep penghindaran risiko ini penting bagi para akuntan, karena ini berarti bahwa investor memerlukan informasi berkenaan dengan risiko tersebut, beserta nilai yang diharapkan dari pengembalian di masa akan datang (Bodie et al., 2005:168; Scott, 2009:71).

Investor individu biasanya diasumsikan menghindari risiko. Dengan demikian, untuk suatu hasil tertentu yang diharapkan dari kegiatan investasi, seorang investor rasional akan menginginkan risiko serendah mungkin. Dengan kata lain, untuk suatu risiko tertentu, investor rasional menginginkan hasil yang diharapkan setinggi mungkin. Investor yang rasional akan menerima pertukaran antara risiko dan tingkat pengembalian (return). Risiko yang lebih tinggi hanya akan ditanggung jika return yang diharapkan lebih tinggi, dan demikian pula sebaliknya.

Pada kegiatan investasi, salah satu cara investor menurunkan risiko untuk suatu tingkat pengembalian tertentu yang diharapkan adalah dengan menggunakan strategi diversifikasi. Artinya, dengan berinvestasi pada suatu portofolio sekuritas. Prinsip diversifikasi menunjukkan bahwa beberapa (namun tidak semua) risiko dapat dihilangkan menggunakan strategi investasi yang tepat. Prinsip ini memiliki implikasi yang tepat untuk sifat informasi risiko yang diperlukan investor.

\section{Keputusan Investasi Optimal dan Risiko Portofolio}

Keputusan suatu portofolio yang terdiri dari dua saham lebih baik daripada hanya satu, maka seharusnya suatu portofolio dengan tiga saham akan lebih baik daripada dua, dan seterusnya. Artinya, jumlah yang sama yang diinvestasikan dalam suatu portofolio dapat menghasilkan risiko lebih rendah dibandingkan jika diinvestasikan dalam suatu perusahaan dengan nilai pengembalian yang sama. Alasannya, karena jika berinvestasi pada lebih dari satu investasi yang berisiko, maka risiko-risiko spesifik bagi perusahaan akan cenderung saling menghapuskan. Jika salah satu saham menghasilkan return yang rendah, selalu ada kesempatan bahwa saham lainnya akan menghasilkan return yang tinggi.

Semakin besar jumlah saham perusahaan yang berbeda-beda dalam suatu portofolio, maka risiko pengembalian semakin menurun. Namun, adanya risiko untuk seluruh pasar maka tidak ada penghapusan seluruhnya. Artinya, faktor-faktor untuk seluruh ekonomi masih akan berkontribusi terhadap risiko pasar, dan risiko tersebut 
tidak dapat didiversifikasi. Risiko-risiko yang tidak dapat didiversifikasikan disebut risiko sistematis (systematic risk), contohnya: tingkat suku bunga, tingkat valuta asing, dan tingkat aktivitas ekonomi. Faktor-faktor spesifik perusahaan, disebut risiko tidak sistematik (unsystematic risk), yang mempengaruhi hasil pengembalian salah satu perusahaan saja, contohnya: kualitas manajemen perusahaan, hak paten baru, pemogokan, dan kerusakan peralatan (Moeljadi, 2006:92; Scott, 2009:76).

Prinsip diversifikasi (Scott, 2009:71) mengarah pada suatu ukuran risiko yang penting dalam teori investasi, yaitu nilai beta, yang mengukur pergerakan yang samasama terjadi antara perubahan-perubahan dalam harga sekuritas dan perubahanperubahan dalam nilai pasar dari portofolio pasar. Bahwa, nilai beta mengukur besarnya risiko sistematis yang disebabkan oleh suatu sekuritas terhadap suatu portofolio. Nilai beta suatu saham adalah suatu komponen penting mengenai kegunaan informasi akuntansi bagi investor. Informasi mengenai beta menungkinkan bagi investor untuk mengestimasi return yang diharapkan dan risiko dari beragam portofolio. Diharapkan berdasarkan informasi tersebut, investor yang rasional dapat membuat suatu keputusan yang optimal.

Dalam mencapai keputusan yang optimal diperlukan keputusan yang tepat. Pasar dikatakan mengambil keputusan yang benar terhadap efek suatu peristiwa jika keputusan yang diambilnya tepat. Keputusan yang tepat adalah keputusan yang sesuai dengan pengaruh peristiwa terhadap nilai perusahaan (Hartono, 2008:529; Samsul, 2006:275). Untuk keputusan yang tepat, pasar seharusnya bereaksi positif terhadap peristiwa yang mengakibatkan naiknya nilai perusahaan atau bereaksi negatif terhadap peristiwa yang mengakibatkan turunnya nilai perusahaan. Reaksi pasar ditunjukkan oleh nilai return tidak normal (abnormal return) yang terjadi. Return tidak normal positif menunjukkan reaksi positif, return tidak normal negatif menunjukkan reaksi pasar negatif. Jika return tidak normal tidak terjadi berarti pasar tidak bereaksi.

\section{Earnings Response Coeefficients}

Perspektif informasi atas decision usefulness merupakan suatu pendekatan laporan keuangan yang mengakui tanggungjawab individu untuk memprediksi kinerja perusahaan di masa akan datang dan memfokuskan pada penyediaan informasi yang berguna untuk tujuan ini. Pendekatan ini mengasumsikan efisiensi pasar sekuritas, mengakui bahwa pasar akan bereaksi terhadap informasi yang berguna dari manapun, termasuk laporan keuangan (Scott, 2009:144). Ada sejumlah alasan yang dapat dikemukakan terkait dengan respon pasar yang berbeda terhadap diumumkannya informasi akuntansi (dalam hal ini pengumuman laba) menurut Scott (2009:154) yaitu : (1) Nilai beta, (2) Struktur modal (capital structure), (3) Persistensi, (4) Kualitas laba (earnings quality), (5) Kesempatan pertumbuhan (growth opportunities), (6) Kesamaan harapan-harapan investor (the similarity of investor expectations), (7) Kemampuan harga memberikan informasi (the informativeness of price). 


\section{SIMPULAN}

Penerapan decision usefulness approach dapat menghasilkan informasi akuntansi yang relevan dan reliabel. Pendekatan decision usefulness merupakan suatu pendekatan terhadap laporan keuangan berbasis biaya historis agar lebih berguna (useful). Agar informasi akuntansi dapat berguna maka dalam penyajiannya harus menekankan pada karakteristik kualitatif dari informasi akuntansi, yaitu informasi yang relevan (relevansi) dan informasi yang reliabel (reliabilitas). Informasi yang relevan ialah informasi yang mempunyai kapasitas untuk mempengaruhi keyakinan investor mengenai future returns, dan seharusnya di-release secara tepat waktu.

Penyajian laporan keuangan (informasi akuntansi) tidak mungkin dengan tingkat reliabilitas dan sekaligus relevansi secara penuh, karena konsekuensinya akan terjadi trade-off antara relevansi dan reliabilitas. Oleh karena itu, untuk mengatasi permasalahan tersebut digunakanlah pendekatan decision usefulness untuk membuat laporan keuangan yang berdasarkan biaya historis menjadi lebih berguna. Untuk mengaplikasikan konsep tersebut diperlukan keterkaitan dengan berbagai teori ilmu ekonomi dan keuangan, seperti: teori investasi dan teori pengambilan keputusan.

Pendekatan decision usefulness mengasumsikan investor adalah individu yang rasional, yaitu individu yang mempertimbangkan trade-off antara tingkat return yang diharapkan dan tingkat risiko yang akan dihadapi dalam keputusan investasinya, dan memilih tindakan yang akan menghasilkan expected utility yang paling tinggi. 


\section{DAFTAR PUSTAKA}

Abarbanell JS, Lanen WN, Verrecchia RE, 1995. Analysts' Forecasts as Proxies for Investor Beliefs in Empirical Research. Journal of Accounting and Economics, 20, pp. 31-60.

Alattar JM, Al-Khater K, 2007. An Empirical Investigation of Users' Views on Corporate Annual Reports in Qatar. International Journal of Commerce and Management, vol. 17 no. 4, pp. 312-325.

Ball R, Brown P, 1968. An Empirical Evaluation of Accounting Income Numbers. Journal Of Accounting Research, pp. 159-178.

Bamber, Barron, Stober, 1997. Trading Volumen and Different Aspects of Disagreement Coincident with Earnings Announcements. The Accounting Review, vol. 71 no. 4, pp. 575-597.

Banker, Das, Datar, 1993. Complementarity of Prior Accounting Information: The Case of Stock Dividend Announcements. The Accounting Review, vol. 68 no. 1, pg. 28.

Beaver WH, 1989. Financial Reporting: An Accounting Revolution. Second Edition. New Jersey: Prentice Hall.

Bodie, Kane, Marcus, 2009. Investment. $8^{\text {th }}$ edition. McGraw-Hill Companies, Inc.

Collins DW, Kothari SP, 1989. An Analysis Of Intertemporal and Cross-Sectional Determinants Of Earnings Response Coefficients. Journal of Accounting and Economics, 11, pp. 143-181.

Day J, 1986. The Use of Annual Reports by UK Investment Analysis. Accounting and Business Research, pp. 295-307.

Dhaliwal DS, Lee KJ, Fargher NL, 1991. The Association Between Unexpected Earnings and Abnormal Security Returns In The Presence of Financial Leverage. Contemporary Accounting Research, vol. 8 no. 1, pp. 20-41.

Easton PD, Zmijewski ME, 1989. Cross-Sectional Variation In The Stock Market Response To Accounting Earnings Announcements. Journal of Accounting and Economics, 11, pp. 117-141.

Eccles, Holt, 2005. Financial Statement and Corporate Accounts: The Conceptual Framework. Property Management, vol. 23 no. 5, pp. 374-387.

Financial Accounting Standard Board, 1978. Objectives of Financial Reporting by Business Enterprises. Statement of Financial Accounting Concepts No. 1. FASB, Stamford, Connecticut, November.

Financial Accounting Standard Board, 1980. Qualitative Characteristics of Accounting Information. Statement of Financial Accounting Concepts No. 2. FASB, Stamford, Connecticut, May.

Gniewosz G, 1990. The Share Investment Decision Process and Information Use: An Exploratory Case Study. Accounting and Business Research, vol. 20 no. 79, pp. 223-230.

Halim A, 2005. Analisis Investasi. Salemba Empat, Jakarta. 
Hartono J, 2008. Teori Portofolio dan Analisis Investasi. Edisi Kelima. Yogyakarta: BPFE.

Haugen RA, 2001. Modern Investment Theory. Fifth Edition. New Jersey: Prentice Hall.

Kim O, Verrecchia RE, 1997. Pre-announcements and Event-Period Private Information. Journal of Accounting and Economics, 24, pp. 395-419.

Kodrat DS, Herdinata C, 2009. Manajemen Keuangan Based On Empirical Research. Yogyakarta: Graha Ilmu.

Landsman WR, 2007. Is Fair Value Accounting Information Relevant and Reliable? Evidence from Capital Market Research. Special Issue: International Accounting Policy, pp. 19-30.

Lawrence, Kercsmar, 1999. Accounting Information Utilization and Judgment Quality In a Stock Investment Task. American Business Review, vol. 17 no. 1, pg. 7.

Louis PP, 1971. Readings in the History of Economic Thought. California: MrCutrhan Publishing Corporation.

Machfoedz M, 1999. Pengaruh Krisis Moneter pada Efisiensi Perusahaan Publik di Bursa Efek Jakarta. Jurnal Ekonomi dan Bisnis Indonesia, vol. 14, no. 1, pp. 37-49.

Maines, Wahlen, 2006. The Nature of Accounting Information Reliability: Inferences from Archival and Experimental Research. Accounting Horizons, vol. 20 no. 4, pp. 399-425.

Moon, Keasey, 1992. Information and Decision Making: a Search for Method and Understanding. Managerial and Decision Economics, vol. 13 no. 5, pg. 44.

Moeljadi, 2006. Manajemen Keuangan: Pendekatan Kuantitatif dan Kualitatif. Jilid 1. Malang: Bayumedia Publishing.

Pappas JL, Hirschey M, 1995. Ekonomi Manajerial. Jilid II. Edisi Keenam. Jakarta: Binarupa Aksara.

Pressman S, 2002. Lima Puluh Pemikir Ekonomi Dunia. Jakarta: PT. RajaGrafindo Persada.

Reilly FK, Brown KC, 2006. Investment Analysis and Portfolio Management. Eighth Edition. South Western: Thomson.

Samsul M, 2006. Pasar Modal dan Manajemen Portofolio. Jakarta: Penerbit Erlangga.

Samuelson WF, Marks SG, 2003. Managerial Economics. $4^{\text {th }}$ Edition. New York: John Wiley \& Sons, Inc.

Sanusi B, 2004. Tokoh Pemikir dalam Mazhab Ekonomi. Jakarta: Penerbit Rineka Cipta.

Scott WR, 2009. Financial Accounting Theory. Fourth Edition. Toronto, Ontario: Pearson Education Canada Inc.

Sembiring ER, 2005. Karakteristik Perusahaan dan Pengungkapan Tanggung Jawab Sosial: Studi Empiris pada Perusahaan yang Tercatat di Bursa Efek Jakarta. Simposium Nasional Akuntansi 8 - Solo, pp. 379-395. 
Siegel G, Marconi HR, 1989. Behavioral Accounting. South_Western Publishing Co., Ohio.

Standar Akuntansi Keuangan, 2009. Kerangka Dasar Penyusunan dan Penyajian Laporan Keuangan. Penerbit Salemba Empat, Jakarta.

Suwarjono, 2008. Teori Akuntansi: Perekayasaan Pelaporan Keuangan. Edisi Ketiga. Yogyakarta: BPFE.

Wignjohartojo P, 1995. Sikap Akuntan Pendidik Dan Pemakai Laporan Keuangan Terhadap Penggunaan Pengembangan Laporan Keuangan Untuk Membuat Keputusan Investasi Pada Saham. Disertasi. Program Pascasarjana. Universitas Airlangga. Surabaya.

Wolk HI, Dood JL, Tearney MG, 2004. Accounting Theory: Conceptual Issues in a Political and Economic Environment. $6^{\text {th }}$ Edition. Thomson, South-Western. 